\title{
OREOPORANTHERA, A NEW ZEALAND "ENDEMIC" PLANT GENUS DISCOVERED IN TASMANIA
}

\author{
by A.E. Orchard and J.B. Davies
}

(with one text-figure)

\begin{abstract}
ORCHARD, A.E. \& DAVIES, J.B., 1985 (31:vii): Oreoporanthera, a New Zealand "endemic" plant genus discovered in Tasmania. Pap. Proc.R.Soc. Tasm. 119:61-63. https://doi.org/10.26749/rstpp.119.61 ISSN 0080-4703. Tasmanian Herbarium, GPO Box 252C, Hobart, Tasmania, and Department of Agriculture, Marine Board Building, Hobart, Tasmania.

Recent collections near Mt Anne in southwestern Tasmania have extended the known range of the previously monotypic New Zealand endemic genus Oreoporanthera to this island. The Tasmanian plants differ from New Zealand's $O$. alpina in a number of floral and vegetative characters and are considered to represent a new species $O$. petalifera. Like $O$. alpina, $O$. petalifer is found on calcareous montane outcrops and the two are clearly closely allied.
\end{abstract}

Key Words:- Poranthereae (Euphorbiaceae), Oreoporanthera, Tasmania.

\section{INTRODUCTION}

In 1969 Hutchinson provided a synthesis of his 50 year's study of the fa mily Euphorbiaceae. He recognised and described 40 Tribes. One of the smaller ones was Tribe 9, Poranthereae Muell.Arg. containing only the type genus Poranthera Rudge with 9 species, and the newly recognised monotypic genus Oreoporanthera $\mathrm{Hutch}$. based on Poranthera alpina Cheesem. of New Zealand. Oreoporanthera was distinguished from Poranthera by being dioecious instead of monoecious, by having its flowers arranged singly in the axils of the upper leaves instead of in heads, by its strictly opposite leaves with strongly recurved margins, and by its flowers, which lacked petals in both sexes and a vestigial ovary in the males. The new genus has been accepted subsequently by Mark \& Adams (1973) and (tentatively) by Moore \& Irwin (1978).

Oreoporanthera alpina is confined to a small number of mountain tops in the northwestern corner of the South Island of New Zeland where it is described as coming from open subalpine communities between 1000 and $1800 \mathrm{~m}$ altitude amongst limestone, marble or granite rocks.

\section{DESCRIPTION AND DISCUSSION}

Recently, one of us (J.B. Davies) found a plant similar to $O$. alpina on karst formations on a ridge (known unofficially as the 'North East Ridge') of $\mathrm{Mt}$ Anne in southwestern Tasmania between $800-1000 \mathrm{~m}$ above sea level. The top of the ridge is predominantly covered by dwarf subalpine rainforest less than about $6 \mathrm{~m}$ in height, dominated by
Nothofagus cunninghamii, Richea pandanfolia and Athrotaxis selaginoides. This dense vegetation is dissected by a series of knife-blade outcrops of dolomite and a number of deep sink holes. Oreoporanthera grows as mats up to about $0.2 \mathrm{~m}$ in diameter exploiting cracks and crevices on these exposed outcrops. Associated species include Dichosciadium ranunculaceum, Oreomyrrhis gunnii, Senecio pectinatus var. pectinatus and a number of ferns including Cystopteris filix-fragilis, Grammitis armstrongii and Asplenium trichomanes. Unusual grasslands develop on the steep slopes of the sinkholes. They are dominated by Poa labillardieri and include Danthonia hibernae-fortunae, Poa gunnii, Agrostis billardierii var. filifolia, Agrostis aemula and Trisetum spicatum.

Comparison of the Tasmanian specimens with descriptions, illustrations and specimens of $O$. alpina revealed that our plant, although very similar in many respects to the New Zealand species, differed in a number of characters. The habit of the plant is generally more lax with usually longer internodes and thinner stems which often lack the longitudinal flecks of purple pigmentation present in $O$. alpina. By contrast $O$. alpina has more erect stems, all except the youngest some what inflated or succulent, with the leaves usually more or less crowded towards the ends of the branches. The Tasmanian plants apparently die back each year to a small woody rootstock, whereas the stems of $O$. alpina seem more woody and possibly persist longer. The stipules of the New Zealand plant are more coriaceous than ours. However, the most important differences lie in the flowers. Like $O$. alpina, our plants are dioecious, but differ in that 

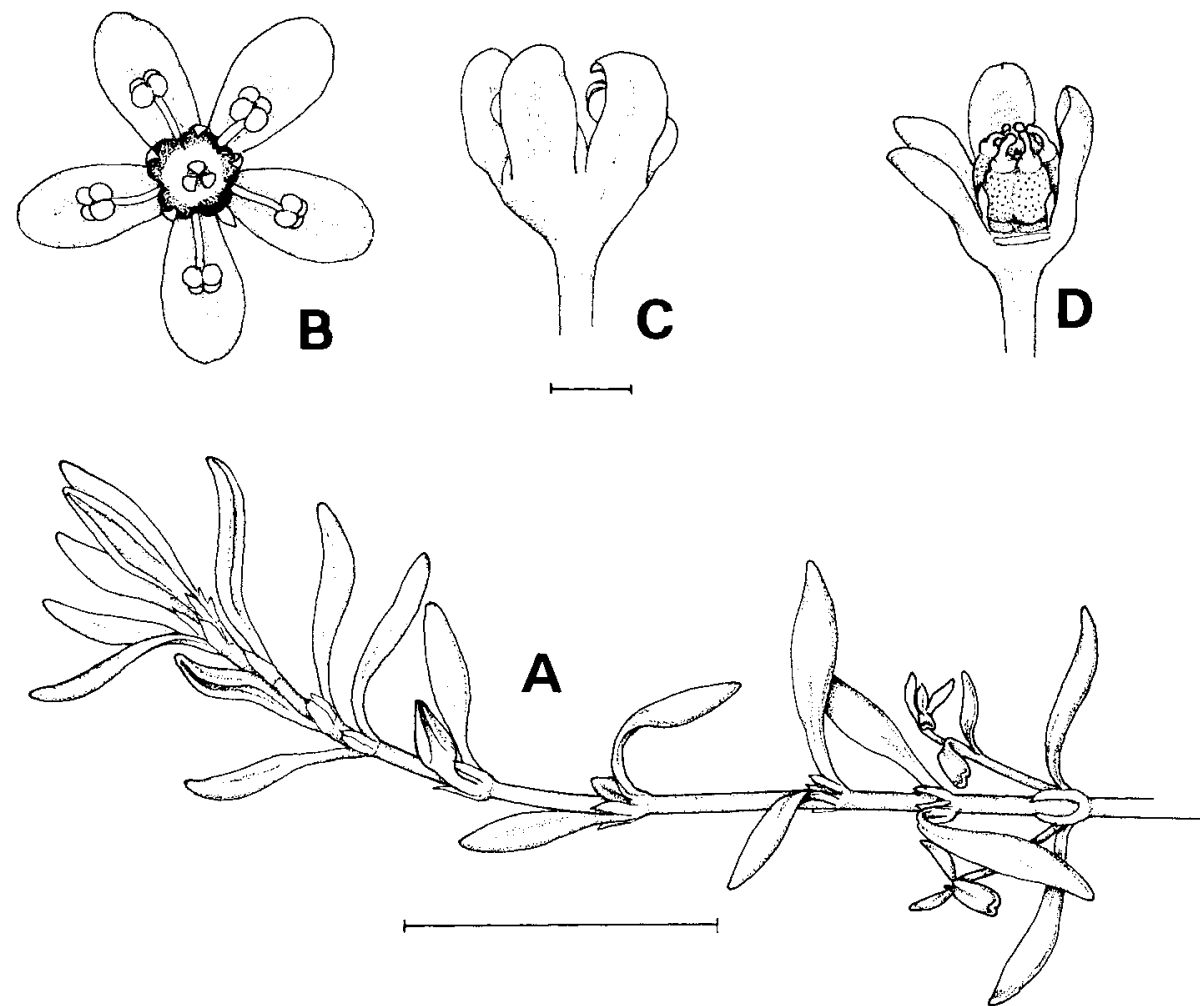

FIG. 1 - Oreoporanthera petalifera. A. Habit of vegetative branch. B. Male flower seen from above, showing vestigial ovary. D. Male flower with sepals closed. C. Female flower, one sepal removed, showing petals, and ovary at an early stage of development towards fruit. Bar scales represent $10 \mathrm{~mm}$ (A) or $1 \mathrm{~mm}$ (B-D). (A-C from Davies 31, D from Buchanan \& Davies 3725).

both the male and female flowers possess small white lanceolate petals, shorter than the sepals. We believe that these differences justify recognition of the Tasmanian plants as a distinct species. described as follows.

\section{Oreoporanthera petalifera Orchard \& Davies, sp. nov.}

Herbae perennes $O$. alpinam simulans, sed habitu laxiore, caulibus gracilioribus, stipulis mollibus albis, et petalis lanceolatis florum masculinorum et femineorum, differt.

Typus: J.B. Davies 31, N.E. ridge of Mt Anne, Tasmania, 31.xii.1984.

Holotypus: HO 88949. Isotypi: CHR, MEL.

Decumbent perennial herb; stems annual, dying back to a slightly woody base, $0.2-0.3 \mathrm{~m}$ long, $1 \mathrm{~mm}$ diam., freely branched, scrambling over rocks and adjacent plants. Leaves opposite, subglossy above, lanceolate, $6-7 \mathrm{~mm}$ long, $1.0-1.7 \mathrm{~mm}$ wide, tapering into a short petiole at base, margins revolute almost to the midrib. Stipules herbaceous, white, obliquely ovate to falcate, $0.8-1.1 \mathrm{~mm}$ long, $0.5 \mathrm{~mm}$ wide, degrading on older branches. Plants dioecious, flowers unisexual, borne singly in the axils of the upper leaves. Male flowers on pedicel 1.3-2.0 mm long; sepals 5, white with greenish central band, oblong to oblanceolate, $1.8-2.0 \mathrm{~mm}$ long, $1 \mathrm{~mm}$ wide, abruptly tapered to obtuse apex or rounded; petals 5 , white, lanceolate, $0.6 \mathrm{~mm}$ long, $0.25 \mathrm{~mm}$ wide, erect, finally becoming incurved between stamens; stamens 5, opposite se pals, filaments $1.2 \mathrm{~mm}$ long, slightly incurved, terete, anthers yellow, 4-celled, depressed globular, 0.3 $\mathrm{mm}$ long, $0.4 \mathrm{~mm}$ diam., opening by terminal pores; ovary vestigial, 3 -lobed, white to greenish, c. $0.3 \mathrm{~mm}$ dia m.; disk green, 5-lobed, with one lobe at base of each petal. Female flowers on pedicel $1.6-2.5 \mathrm{~mm}$ long; sepals 5 , greenish white, linearoblong, $1.6-2.2 \mathrm{~mm}$ long, $0.6 \mathrm{~mm}$ wide, rounded at tip; petals 5 , hyaline, linear to lanceolate, $0.4 \mathrm{~mm}$ 
long, $0.15 \mathrm{~mm}$ wide; ovary globular $0.6 \mathrm{~mm}$ diam., styles divided to base and a pparently 6 ; disk green, broadly 5 -lobed. Fruit depressed globular $1.2 \mathrm{~mm}$ long, $2.0 \mathrm{~mm}$ diam., 6-seeded, explosively loculicidal, leaving a persistent columella on the pedicel/ perianth remains. Seed pale orange brown with a white tesselated pattern superimposed, smooth.

\section{Distribution}

Known only from the dolomite ridge running north and northeast of $\mathrm{Mt}$ Anne in southwestern Tasmania at altitudes between 800 and $1000 \mathrm{~m}$ above sea level, but locally abundant. Flowering December, fruiting in June. Other specimens known: Buchanan \& Davies 3725, north-east ridge of Mount Anne, 29.vi.1984 (HO); Buchanan 5101, $5102,5103,5116,5117,5119$, north-east ridge of Mount Anne, 31.xii.1984 (HO, 5117 also CANB); Davies s.n., Mt Anne, 18.vi.1984 (HO 78671).

\section{STATUS OF THE GENUS OREOPORANTHERA}

Discovery of this species makes a re-examination of the limits and status of the genus Oreoporanthera necessary. O. petalifera is clearly closely related to $O$. alpina yet it disagrees with Hutchinson's description of the genus in having Poranthera-like petals in the male and female flowers, and in having a distinct vestigial ovary in the male flowers. (In fact, Hutchinson was mista ken in believing that $O$. alpina lacked a vestigial ovary in the male flower. Although small, it is certainly present, and is clearly illustrated in Moore \& Irwin (1978).) Furthermore Hutchinson's character of flowers solitary in the axils for Oreoporanthera vs in terminal heads for Poranthera seems to be only a matter of degree. In the Poranthera species that we have examined the terminal heads consist of tightly packed single flowers each subtended by a green leaf-like floral bract, and can consequently be interpreted as only condensed versions of the situation in Oreoporanthera.
However, despite these discrepancies, Oreoporanthera as a genus of two species can still be adequately separated from Poranthera s. str. on three characters: its dioecy, and the fact that its leaves are strictly opposite in arrangement and have strongly recurved margins. The specialised subalpine habitat favoured by the two Oreoporanthera species provides a confirmatory indication that they are different from species of Poranthera which (with the exception of $P$. microphylla) are predominantly lowland plants.

\section{ACKNOWLEDGEMENTS}

Mr. A.M. Buchanan (twice), Dr. B. Potts and Mr. N. Davidson accompanied J.B. Davies on the arduous trek up the North East Ridge where Oreoporanthera grows to collect material at the right stage of development for study. Material of $O$. alpina was kindly loaned for comparative study by the Herbarium, Botany Division, DSIR, Christchurch, New Zealand. Mr. D.I. Morris prepared the line drawings of $O$. petalifer $a$ and identified the grass species. The Botany Department, University of Tasmania, provided financial support for J.B. Davies' vegetation study in the a rea. The authors are grateful for the assistance received from all these sources.

\section{REFERENCES}

HUTCHINSON, J., 1969: Tribalism in the family Euphorbiaceae. Amer.J. Bot., 56: 738-58.

MARK, A.F.\& ADAMS, N.M., 1973: NEW ZEALAND ALPINE PLANTS. A.H. \& A.W. Reed. Wellington, Sydney, London. $265 \mathrm{pp}$.

MOORE, L.B. \& IRWIN, J.B., 1978: THE OXFORD BOOK OFNEWZEALAND PLANTS. Oxford University Press, Wellington, Oxford, New York, $234 \mathrm{pp}$.

(accepted May 3, 1985) 